\title{
Studying a Hybrid System Based on Solid Oxide Fuel Cell Combined With an Air Source Heat Pump and With a Novel Heat Recovery
}

\author{
Vialetto, Giulio; Noro, Marco; Rokni, Masoud
}

Published in:

Journal of Electrochemical Energy Conversion and Storage

Link to article, DOI:

$10.1115 / 1.4041864$

Publication date:

2019

Document Version

Peer reviewed version

Link back to DTU Orbit

Citation (APA):

Vialetto, G., Noro, M., \& Rokni, M. (2019). Studying a Hybrid System Based on Solid Oxide Fuel Cell Combined With an Air Source Heat Pump and With a Novel Heat Recovery. Journal of Electrochemical Energy Conversion and Storage, 16(2), [021005]. https://doi.org/10.1115/1.4041864

\section{General rights}

Copyright and moral rights for the publications made accessible in the public portal are retained by the authors and/or other copyright owners and it is a condition of accessing publications that users recognise and abide by the legal requirements associated with these rights.

- Users may download and print one copy of any publication from the public portal for the purpose of private study or research.

- You may not further distribute the material or use it for any profit-making activity or commercial gain

- You may freely distribute the URL identifying the publication in the public portal 


\section{Studying a hybrid system based on solid oxide fuel cell combined with an air source heat pump and with a novel heat recovery}

\author{
Giulio Vialetto, Marco Noro* \\ Department of Management and Engineering, University of Padova - stradella San Nicola, 3 \\ 36100 Vicenza - Italy \\ e-mail: giulio@giuliovialetto.it, marco.noro@unipd.it
}

Masoud Rokni

Technical University of Denmark, Copenhagen 2800, Denmark

e-mail: mr@mek.dtu.dk

*Corresponding author. Tel.: +39 0444998704 ; Fax: +390444998884

e-mail address: marco.noro@unipd.it

\section{ABSTRACT}

In this paper, a new heat recovery for a micro-cogeneration system based on solid oxide fuel cell and air source heat pump is presented with the main goal of improving efficiency on energy conversion for a residential building. The novelty of the research work is that exhaust gases after the fuel cell are firstly used to heat water for heating/domestic water, and then mixed with the external air to feed the evaporator of the heat pump with the aim of increasing energy efficiency of the latter. This system configuration decreases the possibility of freezing of the evaporator as well, which is one of the drawbacks for air source heat pump in Nordic climates. A parametric analysis of the system is developed by performing simulations varying the external air temperature, air humidity and fuel cell nominal power. Coefficient of performance can increase more than $100 \%$ when fuel cell electric power is close to its nominal $(50 \mathrm{~kW})$, and/or inlet air has a high relative humidity (close to $100 \%$ ). Instead, the effect of mixing the exhausted gases with air may be negative (up to $-25 \%$ ) when fuel cell electric power is $20 \mathrm{~kW}$ and inlet air has $25 \%$ relative humidity. Thermodynamic analysis is carried out to prove energy advantage of such a solution with respect to a traditional one, resulting to be between $39 \%$ and $44 \%$ in terms of primary energy. Results show that the performance of the air source heat pump increases considerably during cold season for climates with high relative humidity and for users with high electric power demand.

Keywords: Adiabatic mixer, air source heat pump, ground source heat pump, micro-cogeneration, solid oxide fuel cell 
NOMENCLATURE

39

Symbol

Meaning

Unit

$40 \quad \mathrm{E}$

electricity

$\mathrm{kJ}, \mathrm{kWh}$

$41 \quad \mathrm{~F}$

fuel (no-renewable primary energy)

$\mathrm{kJ}$

factor

$43 \mathrm{H}$

Heat (both power and energy)

$\mathrm{kW}, \mathrm{kJ}$

specific enthalpy

$\mathrm{kJ} \mathrm{kg}^{-1}$

mass flow rate

$\mathrm{kg} \mathrm{s}^{-1}$

electric power

$\mathrm{kW}$

Primary Energy

$\mathrm{kJ}$

Primary Energy Saving (in percentage)

48 \%PES

heat absorbed by the refrigerant at the evaporator

$\mathrm{kW}$

relative humidity

temperature

$\mathrm{K},{ }^{\circ} \mathrm{C}$

humidity ratio

$\mathrm{kg}_{\text {water }} \mathrm{kg}_{\text {dry air }}{ }^{-1}$

52 W

Meaning

$\begin{array}{lll}54 & \text { Greek } & \text { Meaning } \\ 55 & \eta & \text { Efficiency }\end{array}$

56

57

Subscript

Meaning

58 avail

available

59 aux

auxiliary

60 boiler

boiler

61 DA

dry air

62 ele

electrical system

63 electrical

electrical

64 innov,syst

innovative system

65 inv

inverter

$\begin{array}{ll}66 & 1\end{array}$

liquid

67 no_mixer

system without adiabatic mixer

68 nren

no-renewable

$69 \mathrm{p}$

primary energy

70 sat

saturation

7

thermal

thermal

72 trad,syst

traditional system

trans

transmitted

74 variation

variation

Acronym

Meaning

Unit

77 ASHP

Air Source Heat Pump

78 CHP

Combined Heat and Power

79 COP

Coefficient of Performance

80 DHW

Domestic Hot Water

$\mathrm{kJ}, \mathrm{kWh}$

81 EEL

Electric Equivalent Load 
82 GSHP

83 PEM

84 SOFC

85
Ground Source Heat Pump

Proton Exchange Membrane

Solid Oxide Fuel Cell 


\section{INTRODUCTION}

Low energy buildings are based on the reduction of the primary energy demand through a high insulation level, the use of high efficiency heating/cooling and electricity production systems, and the integration of renewable energy sources. Cogeneration plants, that are systems with combined heat and power production (CHP), may be a viable solution as they can feature a very high "first law of thermodynamics" (energy) efficiency compared to the separate production of the same quantities of heat and power. The extend of the efficiency depends on the type of CHP equipment (as there are many). At the same time, the quality of the efficiency (based on the "second law of thermodynamics", that is exergy) may be very different. Finally, the extend of the energy saving of a cogeneration system depends on the "separate production" reference technologies considered [1]. At the same time, the heat pump (HP) is one of the most efficient heating/cooling systems [2]. The most common heat source for heat pumps in residential buildings is the outside air, seemingly free and easily available. Instead, the energy cost of air movement must be considered. Moreover, the most apparent defect of outside air as a heat source is its decreasing temperature just when the building thermal load is increasing. Thus, in cold weather the heat pump operates with a low coefficient of performance (COP), and with a lower capacity. A hybrid system based on an efficient small scale cogenerator combined with an air source heat pump (ASHP) could be of interest to be analyzed from the energy point of view, because part of the heat could be directed to the evaporator of the heat pump to mitigate the cited drawbacks.

\subsection{Literature review on SOFC small cogeneration systems}

Solid Oxide Fuel Cells (SOFC) are a promising energy generation technology with high efficiency. Different configurations of SOFC based systems were proposed. Rokni investigated different system setups of a hybrid system consisting of SOFCs on the top of a steam turbine fired by natural gas [3]. Pierobon et al. studied a hybrid plant consisting of woodchips gasification system to produce syngas which fuelled a SOFC - organic Rankine cycle to produce $100 \mathrm{~kW}$ electric power [4]. A genetic algorithm was employed to select the optimal working fluid between more than a hundred fluids, and the maximum pressure for the bottoming cycle. The author investigated a similar configuration both from thermodynamic and thermoeconomic point of view, coupling the woodchips gasification system - SOFC to a Stirling engine for combined heat and power with a net electric capacity of $120 \mathrm{~kW}$ [5].

Other studies were focused on the coupling of SOFC and Stirling engines. For example, one of the authors of the present study proposed a novel hybrid power system $(10 \mathrm{~kW})$ for an average family home [6]. The off-gases produced in the SOFC cycle using different fuels were fed to a bottoming Stirling engine, improving the overall electrical efficiency by $10 \%$ relative to that of a stand-alone SOFC plant. In [7], a cogeneration system based on a methane-fed SOFC integrated with a Stirling engine was analyzed from the viewpoints of energy and exergy, varying current density, SOFC inlet temperature, compression ratio and regenerator effectiveness.

Instead, a new hybrid system that couples a solid state two-stage thermoelectric generator to a SOFC was proposed in [8]. The study optimized the number of thermoelectric elements among the top and bottom stages and a relationship between the operating current density of the SOFC and the dimensionless electric current of the optimized thermoelectric generator was derived.

In [9], two new trigeneration systems producing power and heating alongside with cooling based on SOFC fed by either the syngas or biogas were proposed. Through a parametric study, the effects of 
130 some key variables such as the current density and the fuel utilization factor in the systems' 131 performance were investigated.

132 SOFC were already studied for micro-cogeneration systems, especially for the residential sector in 133 cases where the households require a system for both electricity and heat production with a power 134 request wherein the heat to power ratio is changing during the time [10]. In [11], a sensitivity 135 analysis was performed of some common financial metrics to key input parameters (the 136 improvements in electrical efficiency, changes in regulatory policy and changes in the market 137 energy prices) in order to evaluate the economic feasibility of different scenarios.

138 Elmer et al. [12] studied the integration of SOFC with liquid desiccant air conditioning in a tri139 generation system configuration. They highlighted that high tri-generation efficiencies in the range 140 of 68-71\% were attainable. The inclusion of liquid desiccant provided an efficiency increase of 9$14115 \%$ compared to SOFC electrical operation only, demonstrating the potential of the system in 142 building applications that require simultaneous electrical power, heating and/or 143 dehumidification/cooling. The difficulty of the optimization of a SOFC cogeneration plant for one 144 small-scale and one large-scale building under both hot and cold weather conditions was 145 highlighted in [13]. In this study, the authors stated that the results vary widely depending on 146 different system configurations and loading conditions, concluding that SOFC systems should be 147 optimized based on the specific conditions to which they are exposed. More recently, a techno148 economic analysis of an integrated system based on two different types of fuel cell (PEM and 149 SOFC) micro-cogeneration device coupled with an HP for a residential application was presented in 150 [14]. The authors concluded that, even if better performance could be achieved with high 151 temperature and high efficiency fuel cells, PEM systems match a good total efficiency with an 152 already relatively acceptable cost, which could make the investment attractive for the user.

153 In [15] a trigeneration system based on SOFC for domestic applications was modelled and then 154 evaluated under the 4-E assessment criteria: energy, exergy, economy, and environment. Depending 155 on these criteria, the system was multi-objectively optimized by following two operation strategies: off-grid following electrical load and on-grid base load operations. Optimization results showed that the trigeneration system is energetically and economically superior and performs well under both strategies. Fong and Lee [16] proposed a SOFC based micro cogeneration system for residential use in subtropical climate. In an application with significant cooling demand like this, the power generated was used for both air conditioning and electrical appliances, whereas the waste heat was recovered for water heating. An optimal design and control for the thermal energy storage were worked out, concluding that the SOFC-primed micro cogeneration system could have reduction of $26.0 \%$ and $30.8 \%$ in annual primary energy consumption and $\mathrm{CO}_{2}$ emission respectively against the conventional system. Shimoda et al. [17] evaluated the impacts of the dissemination of SOFC (and others) micro-generation in the residential sector on urban- and grid-scale energy systems. They used an urban-scale energy end-use simulation model in order to evaluate the potential contribution of residential cogeneration systems to energy conservation and global warming mitigation on a city scale. As a more general paper, Ramadhani et al. presented a literature survey of the application of SOFC, in particular the optimization strategies [18]. Such a review was based on five features: the decision variable, objective analysis, constraint, method and tools, providing also the future trends of research related to the optimization for SOFC. mobility. For example, the energy-saving effect of a combined use of a residential SOFC 
cogeneration system that adopted a continuous operation, and a plug-in hybrid electric vehicle was discussed by optimal operational planning based on mixed-integer linear programming [19]. Also the authors of the present paper previously investigated the interactions between charging an electric car and a micro-SOFC with an integrated heating system cogeneration system for a household application [20]. In another study [21], the authors analyzed a SOFC, heat pump and Stirling engine system to face heating, domestic hot water and electricity demands for a residential user. A transition from traditional petrol cars to electric mobility was also considered and simulated demonstrating high efficiency of the system with different types of fuel. In [22], one of the possible ways to integrate a heat pump with a micro-combined heat and power based on SOFC technology was presented, in order to increase the overall efficiency of the building heating system. Three different geothermal heat pumping technologies (vapour compression, absorption and adsorption) were studied both from experimental and numerical model (by TRNSYS) [23] point of view. Simulations performed demonstrated that the overall yearly efficiency can be improved up to $30 \%$.

The present authors have already studied performance of heat pump systems applied to heating, ventilation and air conditioning plants, both with ground source heat pumps (GSHP), and with ASHPs. In [24], an evaluation and analysis of data obtained through real time monitoring of a multisource heat pump system in operation were presented. The energy balance indicated that the integration of different sources not only increased the thermal performance of the system as a whole, but also optimized the use of each source. This last concept was further studied in [25] by means of dynamic simulations in TRNSYS [23]. Several scenarios were assessed with respect to primary energy consumption in order to define, given an additional budget for the heat pump system, whether it is a good option to invest in ground source or in solar source for the heating systems. Concerning ASHP, the authors illustrated the energy and economic performance of a gas engine driven heat pump over ten years of operation with respect to district heating solution and other traditional solutions (electric chiller and condensing boilers) [26]. A further assessment of the annual economic and energy profiles of electric and internal combustion engine heat pumps was presented in [27]. The comparison was performed in two cases of maximum flow temperatures to take into account different space heating systems. The analysis showed that natural gas-driven heat pumps can achieve approximately the same efficiency as electrically driven ones powered with electricity from modern natural gas-fired combined cycle power plants.

Recently the authors proposed improvements of energy efficiency of SOFC systems coupled with GSHP for cold climates [28] and with ASHP for warmer climates [29]. In these cases, however, SOFC exhausted gases were used only to heat water for heating and/or domestic hot water production. An innovative operation strategy defined and analysed in [30] was used in those studies. It did not follow electrical or heating demand separately but considered both together. In that strategy, an electric equivalent load (EEL) parameter was defined, which summed the electrical demand for the user, the heat pump, and the electric heater (if used). EEL considered that the heating user demand was covered partly by the SOFC waste heat, partly by the heat pump, and partly by the integration heating system.

One of the main characteristics of SOFC systems is their high temperature in the exhausted gases, which can be used for different purposes. Such a temperature depends on the working condition of the system, and can be as high as e.g. $700{ }^{\circ} \mathrm{C}$ as shown in [6]. Heat recovery on the exhausted gases was studied both in a residential application [31] and in the industrial sector [32], but in a few cases, 
SOFC was combined with absorption chiller as proposed in [33]. Even after heat recovery, SOFC exhausted gases have a valuable enthalpy as they still have a temperature greater than $100{ }^{\circ} \mathrm{C}$. So it could be of interest to use the SOFC exhausted gases to improve energy efficiency of an ASHP in a residential application. Such a technique was already studied by the authors but applied to a heating, ventilation and air conditioning plant set up by a gas engine driven heat pump in an existing historical building [34]. In the present study, the mathematical model of the system and the results of the simulations are described. Here, an effective energy saving is proved. Economic analysis as given in the previous studies of the authors on a similar system indicates potential positive results of such a system in both Northern [28] and Southern climate [29].

\subsection{Aims of the research work}

In this paper, authors study a micro-cogeneration SOFC system with a heat recovery placed after the exhausted gases exit. Such gases are firstly used to heat water for heating/domestic water of a residential user. Then, they are mixed with external air to feed the evaporator of an ASHP with the aim of increasing air temperature at evaporator inlet as much as possible to avoid freezing, thus increasing the COP of the heat pump. The main scope of the study is to evaluate the performance of such an integrated SOFC-HP system for residential application varying the size of the fuel cell and the outdoor air conditions in terms of temperature and humidity. That is: does enhancing air enthalpy at the evaporator inlet of an ASHP by using exhausted gases of a SOFC cogenerator always improve the performance of the system? To the knowledge of the authors, no research has been carried out in such a matter.

\section{METHODS}

The system here proposed is set up by a cogenerator (in this case a SOFC), an ASHP, and an air mixer. Considering a typical residential building, SOFC is supplied by natural gas and provides for electricity. Heat demand, both for domestic hot water (DHW) and space heating, is satisfied firstly by the heat recovered from SOFC exhausted gases. In the configuration here proposed, the SOFC exhausted gases further exchange heat by mixing with inlet air at the evaporator section of an ASHP that is used to fully satisfy building heat demand. This may increase the overall performance of ASHP. It is worth to underline that in this study, the possible direct use of exhausted gases heat is not considered as this possibility would have implied an air heating system for the served building. It is considered that the building is heated by a water based heating system only.

\subsection{Modelling the system}

In the following sections, a description of the main equipment of the small cogeneration system (the

\subsubsection{Solid Oxide Fuel Cell}

SOFC is simulated using the simulation tool DNA (Dynamic Network Analyser) developed at DTU [6]. Natural gas as fuel for SOFC is here considered even if the effectiveness of other fuels (like ammonia, dimethyl ether, ethanol or methanol) was proved in a previous study by the authors [6]. The fuel cell cogenerator is set up by the following components (Figure 2):

- air compressors to compress (106 kPa) the air necessary for the fuel cell system; 
- a catalytic partial oxidation (CPO) to convert the heavier hydrocarbons into methane $\left(\mathrm{CH}_{4}\right)$, hydrogen $\left(\mathrm{H}_{2}\right)$ and carbon oxide $(\mathrm{CO})$;

- a desulfurizer to remove the sulfur from the fuel and avoid fuel cell poisoning;

- heat exchangers to increase plant efficiency, preheating fuel and air using the off-fuel and off-air respectively (CP, RP, FP, AP), and to heat water for space heating as well as for DHW using the exhausted gases (Heat Recovery);

- a burner to increase enthalpy of the unused fuel out of the fuel cell;

- SOFC stacks, with performance calculated by the type developed at DTU Risø National Laboratory [35].

Comparison between the SOFC model developed here with experimental data is validated in Figure 1 , in terms of current density and cell voltage (IV curve). As can be seen, the model capture the experimental data very well at four different cell operating temperatures, varying from $650{ }^{\circ} \mathrm{C}$ to $800{ }^{\circ} \mathrm{C}$. The standard error is less than 0.01 . Different hydrogen and water vapor concentrations are used when developing the model. However, here only the data for $97 \%$ hydrogen with $3 \%$ water vapor concentrations is shown. More details on experiment and calibration procedure can be found in [35].

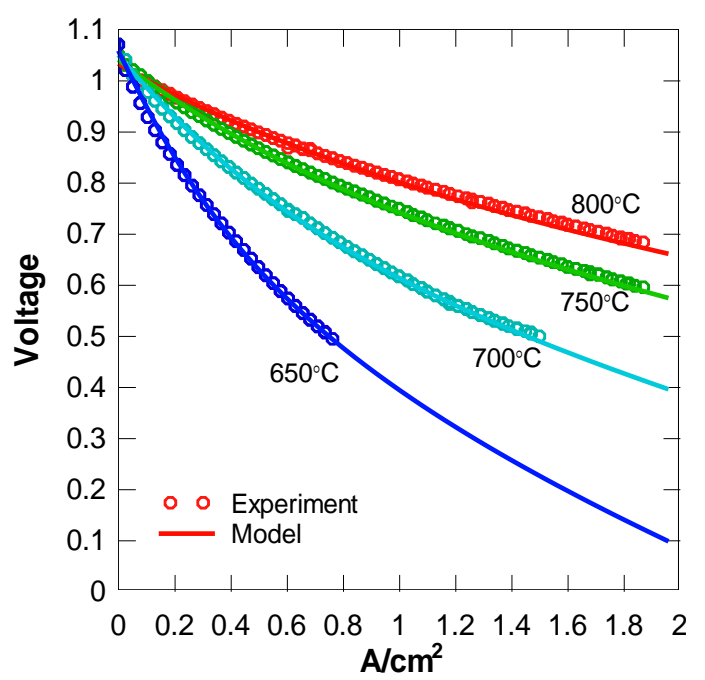

Figure 1. The cell voltage (V) versus current density $\left(\mathrm{A} \mathrm{cm}^{-2}\right)$ and comparison between the model and experimental data with $97 \%$ hydrogen and $3 \%$ water vapor.

Results of simulation and Ref. [5] indicate that compressors' electricity consumption ( $\left.\eta_{\text {aux }}\right)$ is $1.5 \%$ of the electricity produced, while inverter efficiency $\left(\eta_{i n v}\right)$ is assumed to be $92 \%$ [36]. An overall transmitted efficiency $\left(\eta_{\text {trans }}\right)$ is defined considering both auxiliaries and inverter efficiencies (Equation 1):

$$
\eta_{\text {trans }}=\eta_{\text {aux }} \eta_{\text {inv }}
$$

Under such hypothesis, the $\eta_{\text {trans }}$ can be calculated to be $90.7 \%$.

Defining $F_{S O F C}$ as the primary energy consumed by the SOFC (that is the higher heating value multiplied by the fuel rate), $H_{S O F C}$ as the heat available from exhausted gases, and $E_{S O F C}$ as the gross electricity produced, the thermal efficiency $\left(\eta_{\text {thermal,SOFC }}\right)$, the electrical efficiency $\left(\eta_{\text {electrical,SOFC }}\right)$, and the heat-to-power ratio (H/P) of the SOFC plant can be defined as in Equation 2, Equation 3 and Equation 4, respectively: 


$$
\begin{aligned}
& \eta_{\text {thermal }, \text { SOFC }}=\frac{H_{S O F C}}{F_{\text {SOFC }}} \\
& \eta_{\text {eletrical,SOFC }}=\frac{E_{\text {SOFC }}}{F_{\text {SOFC }}} \\
& H / P=\frac{H_{S O F C}}{E_{\text {SOFC }}}
\end{aligned}
$$

293 Table 1 reports the thermodynamic benchmarks of a simulation of the SOFC system with 50 stacks 294 at full load $(50 \mathrm{~kW})$.

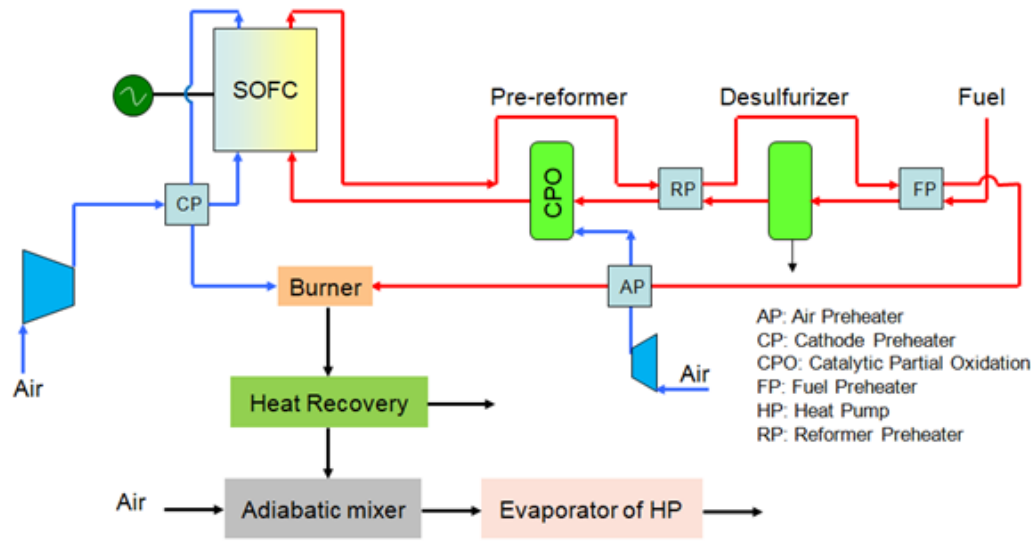

(a)

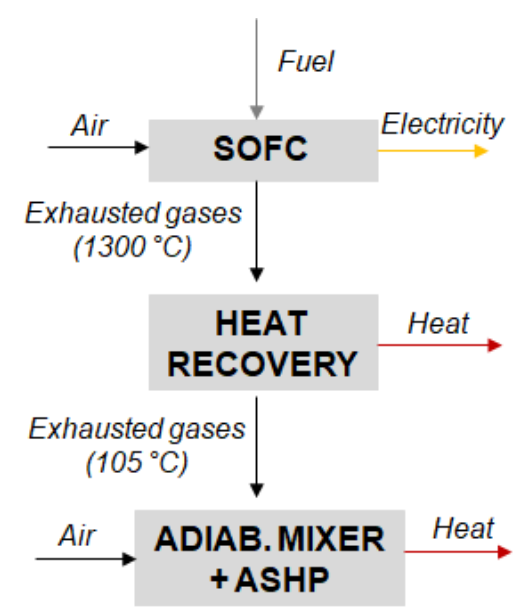

(b)

Figure 2. (a) Representation of SOFC system ([28]-[29]); (b) schematics of the entire system. The air adiabatic mixer to partly recover heat from the exhausted gases of the SOFC is connected after the Heat

Table 1. Efficiencies of the different components of the SOFC system.

\begin{tabular}{l|l}
\hline Parameter & Value \\
\hline $\begin{array}{l}\text { SOFC }(50 \mathrm{~kW}, \text { full load }), \\
\text { thermal efficiency }\end{array}$ & $\eta_{\text {thermal,SOFC }}=0.429$ \\
$\begin{array}{l}\text { SOFC }(50 \mathrm{~kW}, \text { full load }), \\
\text { electrical efficiency } \\
\begin{array}{l}\text { SOFC }(50 \mathrm{~kW}, \text { full load }), \\
\text { heat to power ratio }\end{array}\end{array}$ & $\eta_{\text {electrical }, \text { OFC }}=0.530$ \\
$\begin{array}{l}\text { SOFC auxiliaries consumption, } \\
\text { efficiency on electrical output }\end{array}$ & $\mathrm{H} / \mathrm{P}=0.809$ \\
$\begin{array}{l}\text { Exhausted gas temperature after } \\
\text { Heat Recovery }\end{array}$ & $105^{\circ} \mathrm{C}$ \\
\hline
\end{tabular}

Table 2. Mass composition of SOFC exhausted gases at full load, gas temperature $105^{\circ} \mathrm{C}$.

\begin{tabular}{l|l} 
Composition & Gas percentage \\
\hline $\mathrm{N}_{2}$ & $56.76 \%$
\end{tabular}

\begin{tabular}{l|l} 
Composition & Gas percentage \\
\hline $\mathrm{Ar}$ & $0.59 \%$
\end{tabular}




\begin{tabular}{l|l}
$\mathrm{NO}$ & $0.00 \%$ \\
$\mathrm{SO}_{2}$ & $0.00 \%$ \\
$\mathrm{NO}_{2}$ & $0.00 \%$
\end{tabular}

Table 2 shows the results of the SOFC exhausted gases analysis. Sulphur formation in any form (such as $\mathrm{SO}_{\mathrm{x}}$ ) is avoided thanks to the desulfuriser. If gas mixture is condensed, then condensate may not include any acid. At full-load, it is calculated that the humidity ratio (water mass versus dry air mass) is $0.342 \mathrm{~kg}_{\text {water }} / \mathrm{kg}_{\text {dry_air. }}$ Exhausted gases downstream the burner present very high temperature, so heat can be directly recovered by a heat exchanger (Heat Recovery in Figure 2) to be used for DHW production. Gases are cooled down to just above $100{ }^{\circ} \mathrm{C}$ in order to prevent condensation into the heat exchanger. Adiabatic mixer is then used to recover both sensible and latent heat of exhausted gases before discharging them outside the system. Such components will be further discussed in next section 2.1.3. Flowchart information of SOFC system of Figure 2 is reported in Appendix A.

Note that the selection of a CPO reformer is due to its rapid kinetics and the exothermic nature of its operation. When compared to an adiabatic steam reformer (ASR), the CPO provides better start-up and transient responses and reduces the heat input to the fuel stream, both of which are of significant importance in small-scale power plants.

The thermodynamic results in this study were obtained using the Dynamic Network Analysis (DNA) simulation tool. The program includes a component library, thermodynamic state models for fluids and standard numerical solvers for differential and algebraic equation systems. The component library content models include heat exchangers, burners, dryers, turbo machinery, decanters, energy storages, valves and controllers, among others. The thermodynamic state models for fluids cover most basic fluids and compounds. The equations include mass and energy conservation for all components and nodes together with relations for the thermodynamic properties of the fluids in the system. The total mass balance and energy balance for the entire system is also included to account for heat loss and heat exchange between different components. Ref. [6] provides details about the code and its validation with different studied.

\subsubsection{Heat pump}

The heat pump plays an important role in the system. It recovers heat from exhausted gases at (relative) low temperature. In the previous studies, the authors proposed ground source heat pump for cold climates (such as Denmark) [28] and ASHP for warmer climate (for example Mediterranean climates) [29] to be coupled to the fuel cell system to face the electricity and heating needs of a residential building. Usually, GSHP are more expensive compared to ASHP due to drilling costs and associated heat exchanger. On the other hand, GSHPs have higher COP because ground temperature is usually constant (or assumed) during the year. Air temperature, instead, varies between day and night times and month by month. Therefore, ASHPs have variable COP during the year, and is typically lower during colder periods. It is advisable to consider that in climates where conditions with air temperature just above $0{ }^{\circ} \mathrm{C}$ (especially between 5 and $7{ }^{\circ} \mathrm{C}$ depending on the design of the evaporator finned coil) and relative humidity (RH) above $50 \%$ are more frequent, possibility of freezing of the outdoor heat exchanger (evaporator) may lead to a decrease in seasonal performance of the heat pump. In fact, ice has poor heat transfer capability and reduces available area for air, and so air mass flow rate. For such a reason, defrost of evaporator 
section is periodically necessary. Defrosting can be performed by an auxiliary heat source (electrical resistance or gas burner) or reversing the thermodynamic cycle. In any case, defrosting is quite penalizing for the heat pump energy performance, as it increases its energy consumption. In this paper, the authors propose to mix the exhausted gases exiting the SOFC (Figure 2, and state 1 in Figure 4) with outdoor air (state 2 in Figure 4) with the aim to enhance temperature of inlet air at the ASHP evaporator (state 3 in Figure 4) in order to prevent ice formation.

Heat pumps could be simulated using technical norms, for example UNI 11300-4 [37] to consider different working temperature at condenser/evaporator, and using EN 14825 for partial load operation in heating mode [38]. Such methods have been already used by the authors in [39]. In the present study, the authors propose a regression of technical datasheet of a commercial inverter driven heat pump (Figure 3, Table 3) [40]. The HP uses R410A as refrigerant. The saw tooth plot in heating power between $-7{ }^{\circ} \mathrm{C}$ and $2{ }^{\circ} \mathrm{C}$ is due to the European Heat Pump Association (EHPA) test conditions to get the EHPA quality label. This is a third party testing process based on the guidelines of the EHPA and executed according to the test requirements of the European Norms EN 14511 parts 1 to 4 (unit performance for heating), EN 16147 (sanitary hot water) and EN 1202 (sound). In particular, for inverter driven HP (like the model considered in this study) the performance tests are run varying the frequency of the compressor's electric motor from $100 \%$ (at $7{ }^{\circ} \mathrm{C}$ outdoor air temperature) to $60 \%$ (at $2{ }^{\circ} \mathrm{C}$ ). This is the reason of the decreasing of the heating power between $-7^{\circ} \mathrm{C}$ and $2{ }^{\circ} \mathrm{C}$.

When external air $\mathrm{RH}$ is higher than $50 \%$ and temperature is just above $0{ }^{\circ} \mathrm{C}$, freezing of evaporator may occur. Typically, freezing rate is maximum when air temperature is around $7{ }^{\circ} \mathrm{C}$. A frost factor is considered [41] as multiplying penalty factor to decrease COP of the heat pump to take into account the periodic defrosting. The cited reference proposes a value that is defined as a function of outdoor air temperature in the range of $-10{ }^{\circ} \mathrm{C}$ to $10{ }^{\circ} \mathrm{C}$, and $\mathrm{RH}$ in the range of 50-100 $\%$. The penalty factor is lower given a lower outdoor air temperature up to values just above $0{ }^{\circ} \mathrm{C}$, and the higher RH [41].

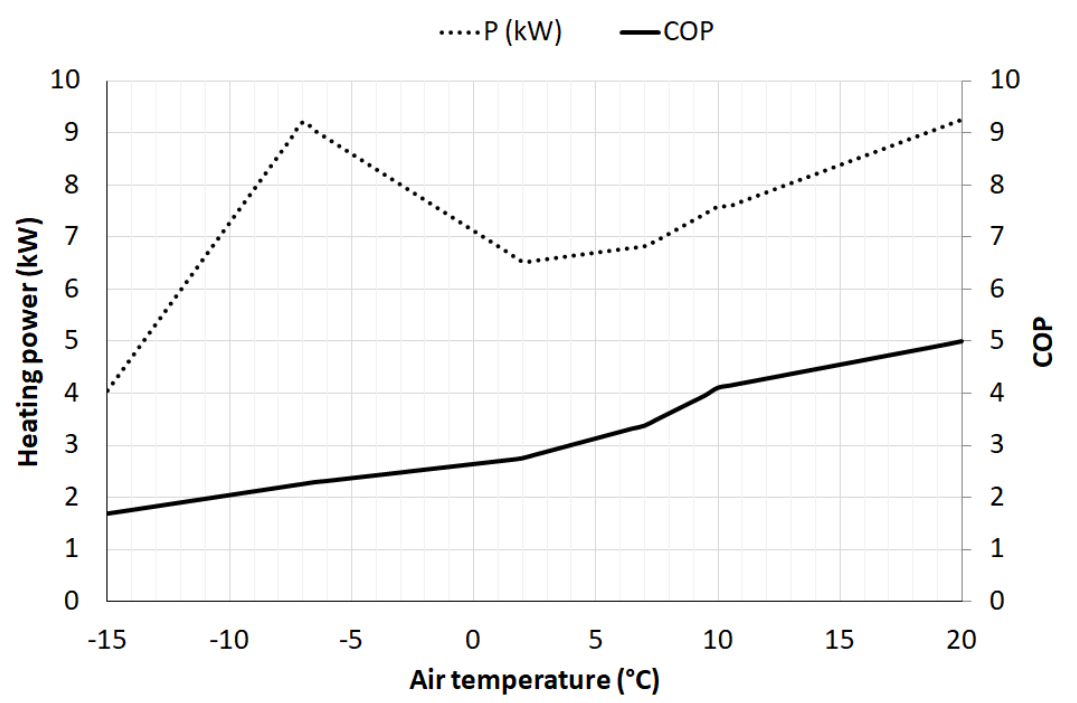

Figure 3. Technical datasheet, relation between nominal heating power and COP and external air temperature ([40]). 


\begin{tabular}{l|l}
\hline Parameter & Value \\
\hline ASHP Nominal Condition & External Air $2{ }^{\circ} \mathrm{C}$ - Condenser \\
Nominal heating power & outlet Water $45^{\circ} \mathrm{C}(\mathrm{A} 2 \mathrm{~W} 45)$ \\
Nominal COP & $6.5 \mathrm{~kW}$ \\
\hline
\end{tabular}

\subsubsection{Adiabatic mixer and evaporator}

As stated in the Introduction section, mixing outdoor air with exhausted gases from the SOFC plant is the main novelty of this research work. This is useful to increase air temperature at evaporator inlet, in order to avoid freezing of evaporator and increasing the COP. Moreover, in such a way heat recovery from the SOFC is increased. In previous works ([20] [21]), the Authors have already proposed to recover heat of SOFC systems: exhausted gases were used to heat water with a heat exchanger for DHW and space heating purpose, with H/P ratio of the overall system around 0.82 . In these cases, gases were discharged with a temperature higher than $100{ }^{\circ} \mathrm{C}$ in order to prevent condensation, and decrease the size of the heat exchanger.

In order to increase the heat recovery and so the total heat available from the system, an adiabatic mixer with external air and an ASHP is proposed in this paper. Figure 4 represents the air mixing system. Firstly, Heat Recovery heat exchanger allows to heat water for DHW and space heating purpose (water outlet temperature $60{ }^{\circ} \mathrm{C}$ ) by decreasing exhausted gases temperature from $1336{ }^{\circ} \mathrm{C}$ to $105{ }^{\circ} \mathrm{C}$. Detailed description can be found in Ref. [42]. SOFC exhausted gases after Heat Recovery heat exchanger (state 1) and outdoor air (state 2) are then mixed in an adiabatic mixer, in order to increase enthalpy of outdoor air. By mixing external air with exhausted gases, an increase of the evaporator inlet flow temperature is obtained. As it will be better describe in section 3, such temperature increase depends mainly on the SOFC electric power, that is on the exhausted gases flow rate, and on the air $\mathrm{RH}$, varying in $1-7{ }^{\circ} \mathrm{C}$ range. For example, mixing air with $\mathrm{RH}=25 \%$ with exhausted gases results in an increase of the evaporator inlet flow temperature between $1{ }^{\circ} \mathrm{C}$ and 3 ${ }^{\circ} \mathrm{C}$, varying the SOFC electric power from $20 \mathrm{~kW}$ to $50 \mathrm{~kW}$. If $\mathrm{RH}=100 \%$, such an increase of the evaporator inlet flow temperature is between $3{ }^{\circ} \mathrm{C}$ and $7{ }^{\circ} \mathrm{C}$. In some cases, humidity condensation may also occur (state 31), for example when outlet air is just above $0{ }^{\circ} \mathrm{C}$ with high relative humidity. Mixture (state 3) is used in the evaporator delivering heat to the ASHP, and then it is discharged (state 4). Humidity condensation may occur also into the evaporator (state 41). As a main result, it is expected to increase both heat production and $\mathrm{H} / \mathrm{P}$ ratio of the system. For example, with SOFC system at full load $(50 \mathrm{~kW})$ and with external air at $12.5{ }^{\circ} \mathrm{C}-100 \% \mathrm{RH}$, ASHP produces about $9.3 \mathrm{~kW}$ of heating power, and H/P increases to 1.022 compared to 0.809 of SOFC only.

As mentioned in section 2.1.1, exhausted gases do not have sulphur formation so even if condensation occurs, it does not include any acids. Heat pump evaporator does not require high performance material as titanium to prevent corrosion. It is supposed that no auxiliary flow inducing system, such as a fan, is necessary as the head pressure available from the fan of the heat pump model here referred (around $80 \mathrm{~Pa}$ ) is supposed to be adequate to face the pressure drop of the mixer (and of the ducts and evaporator) ([40]).

Heat pump and adiabatic mixer subsystem have to recover heat of exhausted gases. Main thermodynamic parameters of these gases are mass flow, temperature and pressure. Pressure and temperature are quite constant even if SOFC electric power varies. Mass flow of the mixing to the evaporator of HP is fixed to $1.292 \mathrm{~kg} \mathrm{~s}^{-1}$ according to datasheet ([40]). Mass flow of exhausted 
gases, instead, is related with SOFC power: the higher the SOFC power, the higher the mass flow of exhausted gases, consequently a lower mass flow of inlet air is necessary. Flowchart information of SOFC system of Figure 4 is reported in Appendix A.

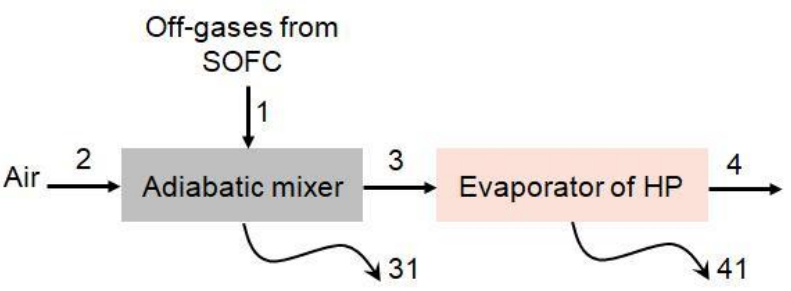

Figure 4. Air mixing system. Curves pointing down represent possible water condensation after the air heat exchange respectively in the mixer (state 31 ) and the evaporator (state 41).

\subsubsection{Mathematical model}

A mathematical model is proposed to describe the components of the system according to equations regarding wet air proposed in [43]. Equations (5) describe the adiabatic mixer:

$$
\left\{\begin{array}{c}
m_{D A, 1}+m_{D A, 2}=m_{D A, 3} \\
m_{D A, 1} * W_{1}+m_{D A, 2} * W_{2}=m_{D A, 3} * W_{3}+m_{l, 31} \\
m_{D A, 1} * h_{1}+m_{D A, 2} * h_{2}=m_{D A, 3} * h_{3}+m_{l, 31} * h_{l, 31} \\
W_{3}=\min \left(\frac{m_{D A, 1} * W_{1}+m_{D A, 2} * W_{2}}{m_{D A, 3}}, W_{s a t, 3}\right)
\end{array}\right.
$$

Equations (5) represent, respectively:

- conservation of dry air mass $\left(m_{D A, 1}\right.$, state 1$)$, dry exhausted gases $\left(m_{D A, 2}\right.$, state 2$)$ and dry air mixture $\left(m_{D A, 3}\right.$, state 3$)$;

- conservation of water mass flow rate. $W_{1}, W_{2}, W_{3}$ are the humidity ratio in states 1,2 and 3 , respectively, $m_{l, 3}$ is the liquid mass flow rate in case of humidity condensation in the adiabatic mixer;

- conservation of energy. $h_{1}, h_{2}, h_{3}$ are the specific enthalpy in states $1,2,3$, respectively, the values depend on air temperature and humidity ratio. $h_{l, 3}$ is the enthalpy of condensate water $m_{l, 3}$.

$W_{\text {sat }, 3}$ is the humidity ratio in state 3 in saturation condition, depending only on air temperature in state 3 (total pressure is assumed to be $101325 \mathrm{~Pa}$ ). If $W_{s a t, 3}$ is lower than weighted average of humidity ratio in states 1 and 2 condensation occurs.

Equations (6) describe the evaporator:

$$
\left\{\begin{array}{c}
m_{D A, 3}=m_{D A, 4} \\
m_{D A, 3} * W_{3}=m_{D A, 4} * W_{4}+m_{l, 41} \\
m_{D A, 3} * h_{3}=m_{D A, 4} * h_{4}+m_{l, 41} * h_{l, 41}+Q \\
W_{4}=\min \left(W_{3}, W_{s a t, 4}\right)
\end{array}\right.
$$

Equations (6) represent, respectively: 
- conservation of dry air mixture mass. $m_{D A, 3}, m_{D A, 4}$ are the dry air mixture mass flow rate in states 3 and 4, respectively;

- conservation of water mass. $W_{3}, W_{4}$ are the humidity ratio values in states 3 and 4 , respectively, $m_{l, 4}$ is the liquid mass flow rate in case of humidity condensation in the evaporator;

- conservation of energy. $h_{3}, h_{4}$ are the specific enthalpy in states 3 and 4 , respectively, they depend on air temperature and humidity ratio. $h_{l, 4}$ is the enthalpy of condensate water $m_{l, 4}$ and $Q$ is the heat absorbed by the refrigerant at the heat pump evaporator.

$W_{\text {sat }, 4}$ is the humidity ratio in state 4 in saturation condition, depending only on air temperature in state 4 . If $W_{\text {sat, } 4}$ is lower than humidity saturation in state 3 condensation occurs.

The heat pump is expected to increase its performances because of the higher air enthalpy at the evaporator inlet. This is due to both the higher temperature and the higher humidity ratio, that is both sensible and latent terms contribute to the enhancement of enthalpy due to the adiabatic mixer.

\subsection{Simulation of the system}

A steady-state analysis is performed with the aim of studying energy performance of the system at different operation conditions. The analysis is performed by varying the dry bulb air temperature from $-7.5{ }^{\circ} \mathrm{C}$ to $15{ }^{\circ} \mathrm{C}$ with a step of $2.5{ }^{\circ} \mathrm{C}$, $\mathrm{RH}$ from $25 \%$ to $100 \%$ with a step of $25 \%$, and SOFC nominal electric power from 20 to $50 \mathrm{~kW}$ (step of $10 \mathrm{~kW}$ ). For the sake of brevity, only some of the values, namely outdoor air relative humidity and SOFC nominal electric power, are presented in next section 3 to compare very different situations, $25 \%-20$ to $50 \mathrm{~kW}$, and $100 \%-20$ to 50 $\mathrm{kW}$. Varying SOFC nominal electric power is advisable because it affects the exhausted gases flow rate entering the adiabatic mixer. The ASHP chosen (Table 3) allows to have consistent mass flow rates between heat pump evaporator and SOFC.

\subsubsection{Analysis of the coefficient of performance}

The simulations allow to calculate air temperature at the evaporator outlet (state 4 in Figure 4), as well as the COP of the heat pump. The main aim of the proposed system is to increase the COP of the ASHP. As mentioned in section 2.1.2, COP is a function of air temperature and relative humidity. A high value of the latter is useful to improve the COP because of the latent heat of condensation of water. This increases the heat exchange inside the evaporator, under the assumption that the finned coil surface temperature is not below $0{ }^{\circ} \mathrm{C}$. Otherwise, frost may grow in the fins reducing heat exchange between air and refrigerant. As already cited in section 2.1.2, this may occur more frequently when air temperature at the evaporator inlet is between $5{ }^{\circ} \mathrm{C}$ and $9{ }^{\circ} \mathrm{C}$. In such a case, a defrost factor has to be considered [44] to take into account the penalization of COP due to periodic defrosting of the evaporator with finned coil (e.g. by reversing the cycle). Analysis of COP variation between a traditional ASHP (without the adiabatic mixer, $C O P_{\text {no_mixer }}$ ) and the current innovative system $\left(C O P_{\text {innov,syst }}\right)$ is performed and presented for four very different representative cases by a combination of external air RH and SOFC nominal power $(25 \%-20 \mathrm{~kW}$, $25 \%-50 \mathrm{~kW}, 100 \%-20 \mathrm{~kW}$, and $100 \%-50 \mathrm{~kW}$ ) (Equation 7):

$$
C O P_{\text {variation }}=\left(\frac{\text { COP }_{\text {innov,syst }}}{C O P_{\text {no_mixer }}}-1\right) \cdot 100
$$


$C O P_{\text {variation }}$ higher than zero means that the innovative system has a higher COP than the one without mixer, and therefore ASHP performs better.

\subsubsection{Analysis of the Primary Energy Saving}

Analysis on primary energy saving (\%PES) is also proposed, wherein the innovative system is compared with a traditional one with separate production of heat (boiler) and electricity (national grid) in terms of primary energy ( $P E_{\text {innov,syst }}$ and $P E_{\text {trad,syst }}$ respectively). Considering that the system here proposed has a net available electricity generation $E_{\text {avail }}$ (that is the difference between SOFC net electric power and ASHP consumption) and a heat generation $H_{\text {avail }}$ (that is the sum of heat cogenerated by SOFC and generated by ASHP), \%PES benchmark is defined as Equation (8):

$$
\% P E S=\left(1-\frac{P E_{\text {innov,syst }}}{P E_{\text {trad }, \text { syst }}}\right) \cdot 100=\left(1-\frac{\frac{E_{\text {avail }}+\frac{H_{\text {avail }}}{\eta_{\text {ele }}}}{\eta_{\text {boiler }}}}{F_{\text {SOFC }}}\right) \cdot 100
$$

where $F_{S O F C}$ is the fuel (primary energy) consumption of SOFC, $\eta_{\text {ele }}$ is the global electric efficiency from grid (assumed to be 0.439 ), and $\eta_{\text {boiler }}$ is the efficiency of boiler for heat production (assumed to be 0.9). The former has been fixed on the basis of the (relative) fast increase during the last 15 years in Italy, due to large diffusion of renewable energies (mainly PV and wind) and to the repowering of old thermoelectric plants by combined Brayton-Joule gas turbine and steam turbine cycles. Moreover, $\eta_{\text {boiler }}$ has been fixed by referring to condensing boilers that can have a mean seasonal thermal efficiency of 0.9 with respect to HHV. Such a definition is consistent with that of the primary energy saving of cogeneration systems as referenced in the 2012/27/EU Energy Efficiency Directive [45] and Directive 2004/8/EC on promotion of cogeneration [46].

\section{RESULTS AND DISCUSSION}

The simulation of the innovative system here proposed allows to investigate in which conditions it is more energy advantageous with respect to traditional systems (ASHP with no adiabatic mixer, and separate production of heat and electricity). Main results for the representative cases described in section 2.2 are here reported in terms of evaporator outlet temperature, COP and PES of the proposed system.

\subsection{Evaporator outlet air temperature}

Firstly, the difference in evaporator outlet temperature (airside, $T_{4}$ ) between ASHP standalone (only ASHP) and ASHP-SOFC integrated system in function of external air temperature $T_{2}$ is outlined (Figure 5). The subscripts of the temperatures refer to the states of air or air/exhausted gases flows as described in Figure 4. In both cases considered as described in section $2.2(25 \%-20 \mathrm{~kW}$, and $100 \%-50 \mathrm{~kW}$ ), temperature at the evaporator outlet is higher in ASHP-SOFC system because of the positive effect of high temperature of the exhausted gases from SOFC. The higher the SOFC electric power, the higher the temperature difference between the two systems is found to be. For example, for $T_{2}=0{ }^{\circ} \mathrm{C}$, evaporator outlet temperature $T_{4}$ is $3{ }^{\circ} \mathrm{C}$ higher with ASHP-SOFC system with respect to ASHP only in case $(25 \%-20 \mathrm{~kW})$. At same external air temperature, $T_{4}$ is $10{ }^{\circ} \mathrm{C}$ higher in case $(100 \%-50 \mathrm{~kW})$. The reason is due to the increasing of airflow rate with the increasing of SOFC nominal power. 
Even if the increasing of temperature of discharged gases (state 4, Figure 4) is proved, COP may or may not increase. If evaporator temperature is between $-7.5^{\circ} \mathrm{C}$ and $10{ }^{\circ} \mathrm{C}$ and $\mathrm{RH}$ is higher than 50 $\%$, then the frost factor shall be considered, which can affect the energy performance of the heat pump.

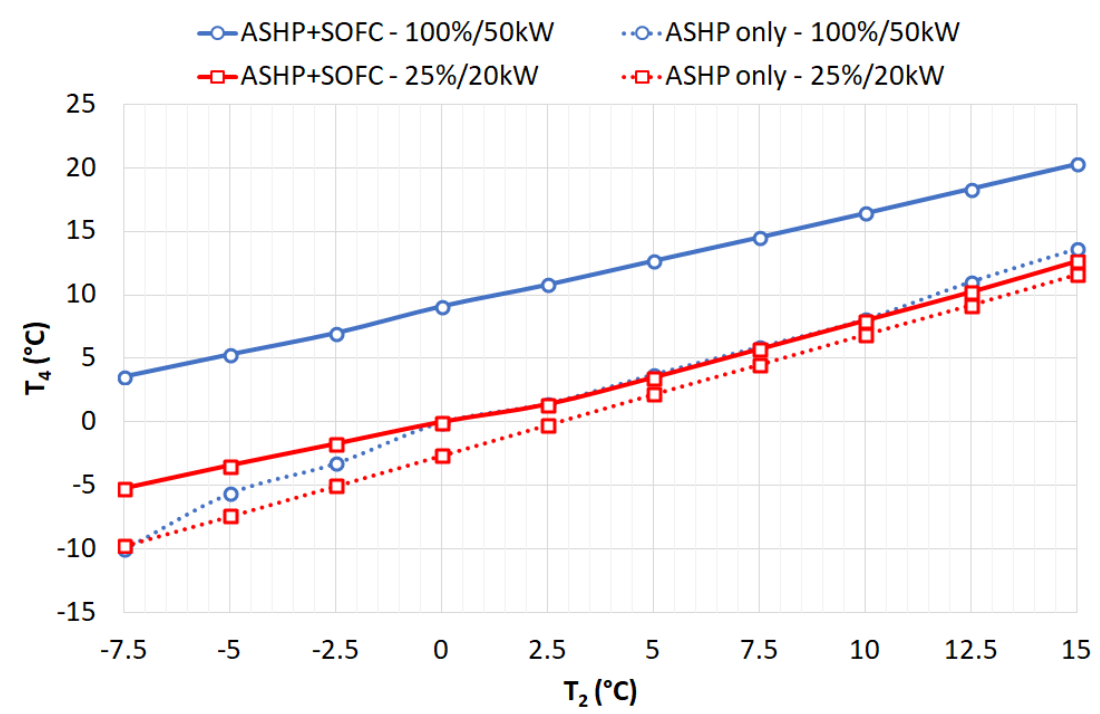

Figure 5. Evaporator outlet air temperature $\left(T_{4}\right)$ in function of external air temperature $\left(T_{2}\right)$ in the two cases (air RH - SOFC nominal electric power), $25 \%-20 \mathrm{~kW} ; 100 \%-50 \mathrm{~kW}$.

\subsection{Coefficient of performance}

Figure 6 compares the COP of the presented system $\left(C O P_{\text {innov,syst }}\right)$ with that of ASHP only $\left(C O P_{\text {no_mixer }}\right)$, considering the two very different cases previously described: low external air relative humidity with low SOFC nominal electric power (respectively $25 \%$ and $20 \mathrm{~kW}$ ), and high external air relative humidity with high SOFC nominal electric power (respectively $100 \%$ and 50 $\mathrm{kW}$ ). It is apparent that the system proposed here is not always advantageous. The latent heat contribution of SOFC exhausted gases may be greater than the sensible one and therefore more frequent defrosting is requested when air temperature is in the critical range $\left(5-9{ }^{\circ} \mathrm{C}\right.$ as already stated). The higher weight of the frost factor may decrease the COP of the innovative system. For low values of RH and power $(25 \%-20 \mathrm{~kW}), C O P_{\text {innov,syst }}$ is lower than $C O P_{\text {no_mixer }}$ when external air temperature is lower than about $8.5^{\circ} \mathrm{C} . \mathrm{COP}_{\text {no_mixer }}$ ranges from 2 to 3 , whereas $C O P_{\text {innov,syst }}$ ranges from 1.7 to 3 . However, in the case of $100 \%-50 \mathrm{~kW}$, the higher exhausted mass flow rate

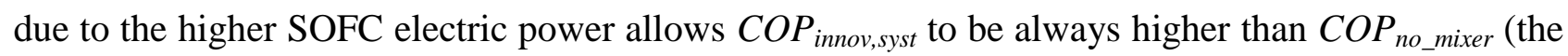
former is between 2.1 and 4.8 , the latter is between 1.7 and 4 ). 


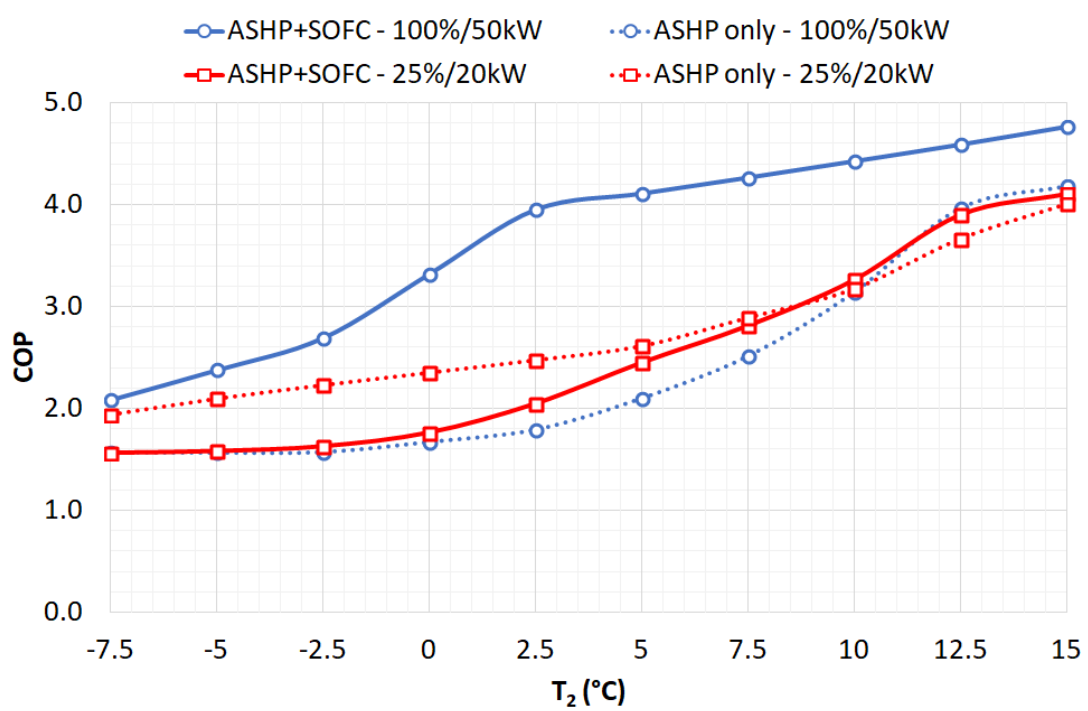

Figure 6. COP in function of external air temperature $\left(T_{2}\right)$ in the two cases (air RH - SOFC nominal electric power), $25 \%-20 \mathrm{~kW} ; 100 \%-50 \mathrm{~kW}$.

Figure 7 and Figure 8 depict $C O P_{\text {variation }}$ with varying outdoor air temperature for different representative cases by a combination of external air $\mathrm{RH}(\mathrm{RH}=25 \%$ and $\mathrm{RH}=100 \%)$ and SOFC nominal power (from 20 to $50 \mathrm{~kW}$ ). $C O P_{\text {variation }}$ is influenced by:

- inlet air RH. Given a fixed amount of SOFC power, $C O P_{\text {variation }}$ increases with increasing $\mathrm{RH}$ of the air. For example, comparing Figure 7 to Figure 8, the present system with $30 \mathrm{~kW}$ SOFC nominal power has a COP lower than the traditional one $\left(C O P_{\text {variation }}\right.$ is $\left.-22 \%\right)$ at 0 ${ }^{\circ} \mathrm{C}$ and $25 \%$ external air condition. $C O P_{\text {variation }}$ exceeds $40 \%$ if inlet air has $\mathrm{RH}=100 \%$;

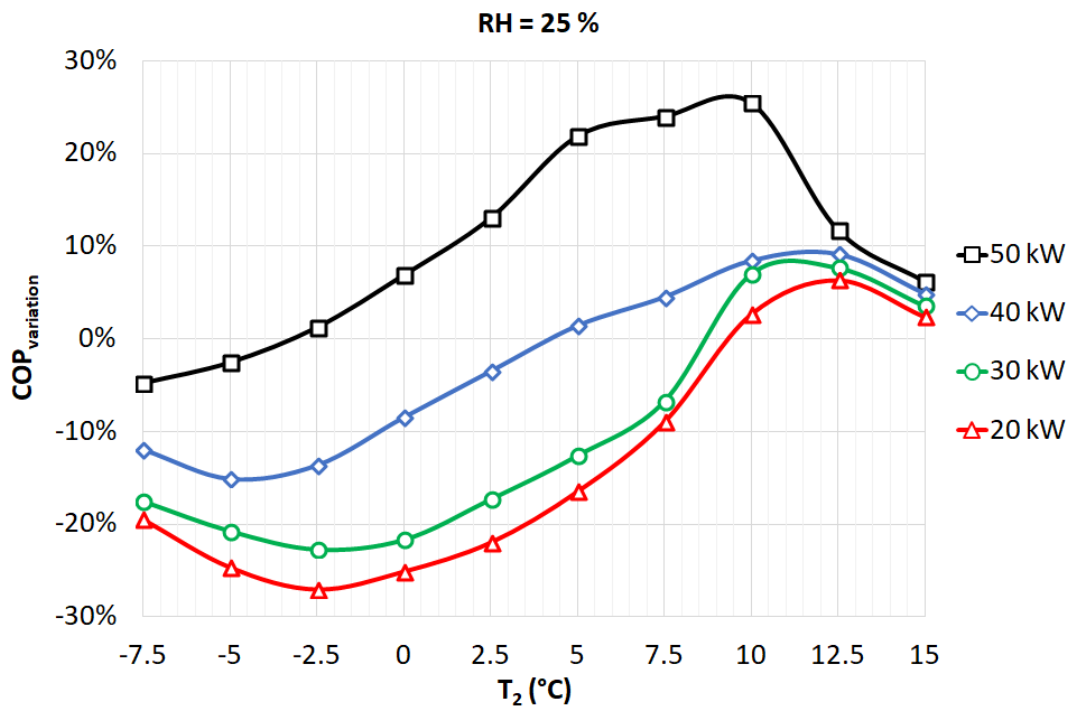




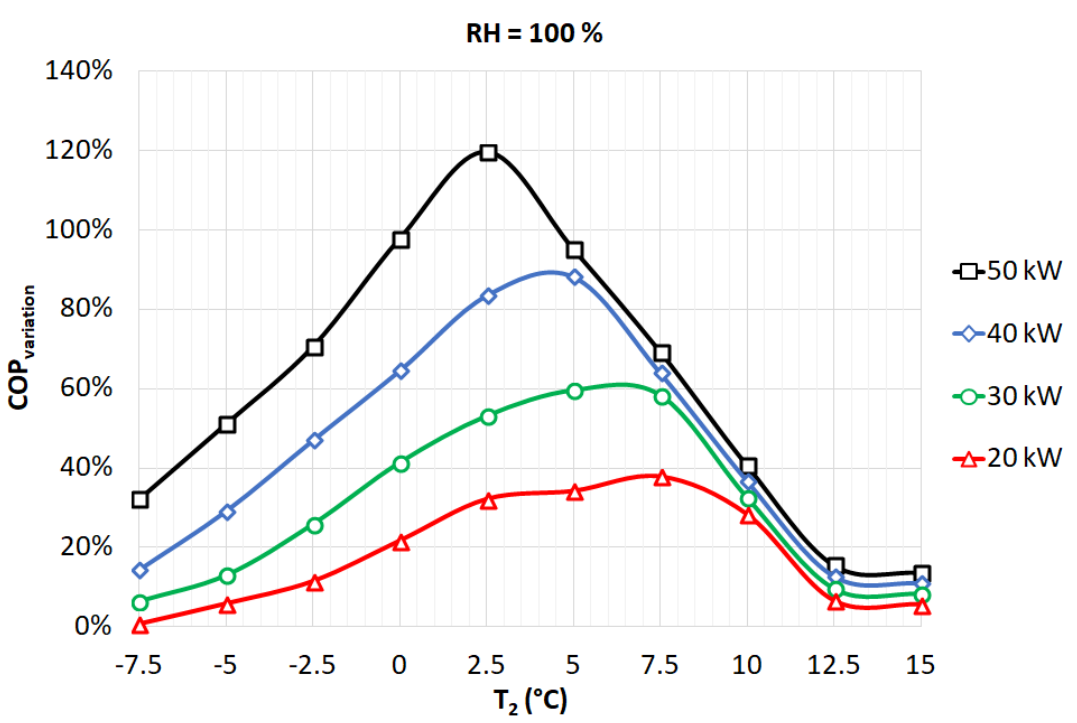

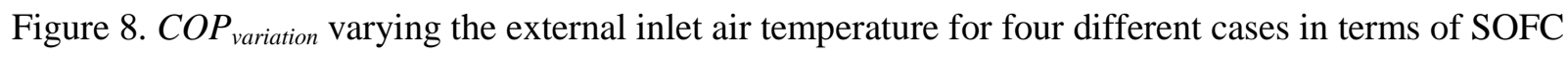
nominal power, air $\mathrm{RH}=100 \%$.

- SOFC electric power. The higher the SOFC power, the higher the mass flow rate of exhausted gases, so higher the temperature of the gases at the outlet of the adiabatic mixer. This parameter has a strong effect on system performances. Figure 7 shows that for inlet air temperature equal to $2.5{ }^{\circ} \mathrm{C}, C O P_{\text {variation }}$ increases from a negative value $(-17 \%)$ to a positive value (13\%) when considering a SOFC power of $20 \mathrm{~kW}$ and $50 \mathrm{~kW}$, respectively. Such an improvement becomes even more interesting at higher air humidity (Figure 8) as $C O P_{\text {variation }}$ increases from $32 \%$ up to $120 \%$.

The main conclusion of this reasoning is that the adiabatic mixer has a positive effect on the heat pump COP when outdoor air has high relative humidity, and when SOFC electric power is high. When SOFC power is $50 \mathrm{~kW}$, COP of heat pump is always improved by the mixer. If a $20 \mathrm{~kW}$ SOFC is used, then the present system has higher COP only when relative humidity of the inlet air is close to $100 \%$.

Figure 7 and Figure 8 show another interesting aspect of the system: the higher air RH and SOFC power, the lower air temperature at which maximum $C O P_{\text {variation }}$ occurs. If inlet air temperature is above $12.5^{\circ} \mathrm{C}$, the adiabatic mixer is not useful at all.

\subsection{Primary Energy Saving}

Based on Equation (5), \%PES is defined to quantify primary energy saving of the proposed system $\left(P E_{\text {innov,syst }}\right)$ compared to the traditional solution $\left(P E_{\text {trad,syst }}\right)$. Figure 9 depicts $\% P E S$ as a function of the outdoor air temperature for four different cases as in Figure 7 and Figure 8, very different cases but representative: $25 \% \mathrm{RH}-20 \mathrm{~kW}, 25 \% \mathrm{RH}-50 \mathrm{~kW}, 100 \% \mathrm{RH}-20 \mathrm{~kW}$, and $100 \% \mathrm{RH}-50$ $\mathrm{kW}$. The proposed system allows a primary energy saving in the range of $37.5 \%-45 \%$. When relative humidity is low ( $\mathrm{RH}=25 \%$ ), the system with relatively small SOFC power presents lower $\%$ PES compared to the case with relatively high SOFC power only for temperature below $2.5{ }^{\circ} \mathrm{C}$. Such critical value of air temperature decreases to $0.5^{\circ} \mathrm{C}$ when humidity is high (RH close to 100 $\%)$. 
601 The higher the relative humidity, the higher \%PES in the given temperature range of $T_{2}$ (dotted 602 lines are always above continuous lines in Figure 9). It is also worth to note that primary energy 603 saving depends also on the partial load operation of SOFC. This is due to variation of power ratio, 604 and thereby to the efficiency of SOFC.

605 Primary energy saving depends on the value of the global electrical efficiency, that is the efficiency 606 not only due to the production of electricity to drive the machine, but also due to the energy 607 transformations to produce it. Such a figure can largely vary due to the mix of energy source of a 608 country. Figure 10 reports the sensitivity of \%PES for a global electrical efficiency varying between 6090.40 (typical of old Rankine cycle based thermoelectric plants) to 0.55 (as for modern Brayton610 Joule turbogas based plant) for $T_{2}=0{ }^{\circ} \mathrm{C}$. Primary energy saving is very sensitive to such a 611 parameter, and it is greater the lower the electrical efficiency. For example, nowadays in Italy $612 \%$ PES is around $35 \%$ whereas electrical efficiency is equal to $51.3 \%$, corresponding to a no613 renewable primary factor $f_{p, n r e n}$ to convert electricity to primary energy fixed at 1.95 according to 614 Italian standard DM 26/06/2015 [47]. The higher the SOFC power, the higher the sensitivity.

615

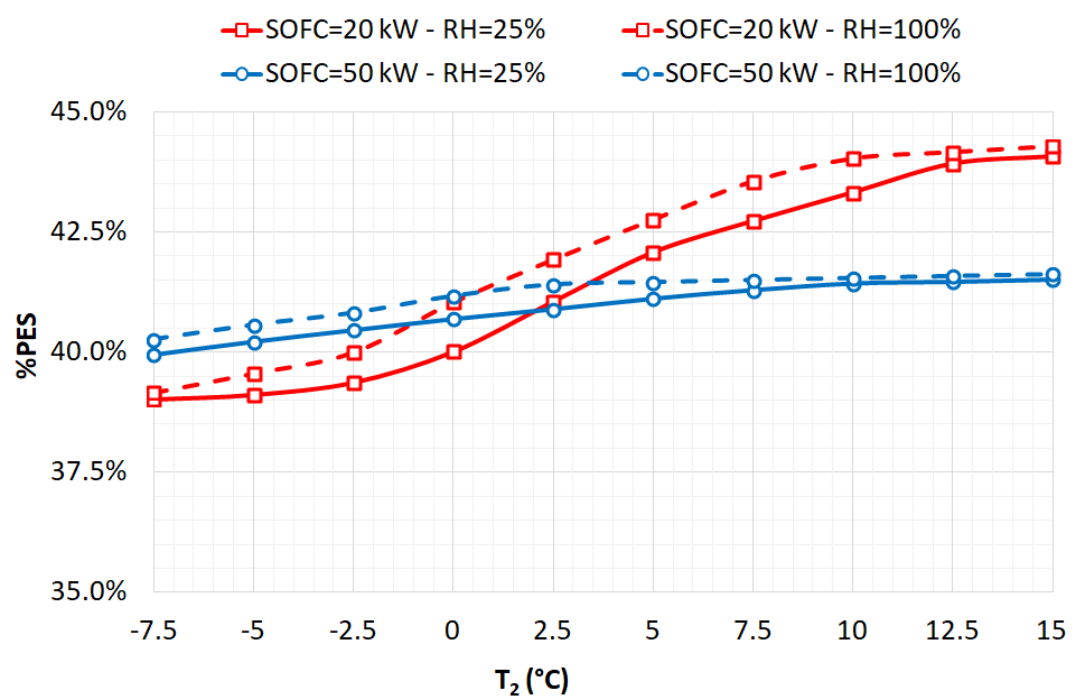

Figure 9. Primary energy saving varying the external inlet air temperature for four very different cases in terms of SOFC nominal power and air relative humidity. 


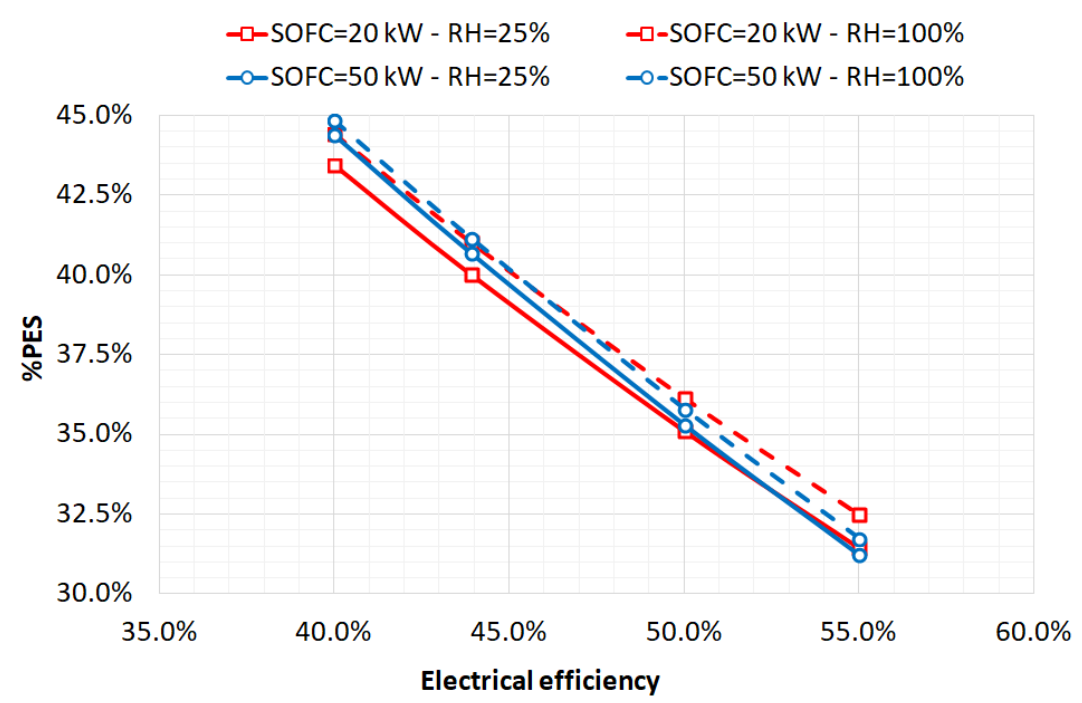

Figure 10 . Sensitivity of the $\% P E S$ with the grid electrical efficiency $\left(T_{2}=0{ }^{\circ} \mathrm{C}\right)$.

\section{CONCLUSIONS}

In this study, a cogeneration system based on SOFC integrated with a heat pump to produce electricity and heat is analysed. An ASHP combined with an advanced heat recovery system is used to increase the overall heat production. Outdoor air entering the evaporator of heat pump is mixed with exhausted gases from the SOFC plant aiming to increase the evaporator temperature and thereby reducing possibility of freezing. Such conditions allow increasing the COP for the heat pump.

The study analyzes the variation on COP and PES varying the external air temperature, air humidity and SOFC nominal power. The results show that in some cases mixing the exhausted gases with air has a negative effect. For example, when SOFC electric power is lower in comparison to its nominal power $(50 \mathrm{~kW})$ and/or inlet air has a low relative humidity, than the heat pump COP decreases down by $35 \%$. On the other hand, COP increases by about $100 \%$ when SOFC electric power is close to its nominal, and/or inlet air has a high relative humidity.

A comparison based on primary energy consumption between the system proposed here and a traditional one, which has a separate production system with electricity from national grid and heat covered by a boiler, proves a significant saving that is between $39 \%$ and $44 \%$. Results of the present work show that enhancing air enthalpy at the evaporator inlet of an ASHP by using exhausted gases of a SOFC cogenerator does not always improve the performance of the system. The effects depend on the external air temperature and humidity, and on the SOFC power. The present study on the integrated SOFC-ASHP system gives the base for a further development based on an energy scenario where distributed energy generation for household application is proposed. In such a scenario, an annual energy analysis can be implemented on the basis of hourly climate data of a specific resort, electrical and thermal loads of the considered building and/or application, in order to evaluate primary energy saving with respect to more traditional solutions. 


\section{REFERENCES}

[1] Marrasso, E., Roselli, C., Sasso, M., Picallo-Perez, A., Sala Lizarrag, J.M., Dynamic simulation of a microcogeneration system in a Spanish cold climate, Energy Conversion and Management, Vol. 165, pp 206-218, 2018.

[2] Lazzarin, R., Dual source heat pump systems: Operation and performance, Energy and Buildings, Vol. 52, pp 77-85, 2012.

[3] Rokni, M., Thermodynamic analysis of an integrated solid oxide fuel cell cycle with a rankine cycle, Energy Conversion and Management, Vol. 51, pp 3724-3732, 2010.

[4] Pierobon, L., Rokni, M., Larsen, U., Haglind, F., Thermodynamic analysis of an integrated gasification solid oxide fuel cell plant combined with an organic Rankine cycle, Renewable Energy, Vol. 60, pp 226-234, 2013.

[5] Rokni, M., Thermodynamic and thermoeconomic analysis of a system with biomass gasification, solid oxide fuel cell (SOFC) and Stirling engine, Energy, Vol. 76, pp 19-31, 2014.

[6] Rokni, M., Thermodynamic analysis of SOFC (solid oxide fuel cell) - Stirling hybrid plants using alternative fuels, Energy, Vol. 61, pp 87-97, 2013.

[7] Hosseinpour, J., Sadeghi, M., Chitsaz, A., Ranjbar, F., Rosen, M.A., Exergy assessment and optimization of a cogeneration system based on a solid oxide fuel cell integrated with a Stirling engine, Energy Conversion and Management, Vol. 143, pp 448-458, 2017.

[8] Zhang, H., Xu, H., Chen, B., Dong, F., Ni, M., Two-stage thermoelectric generators for waste heat recovery from solid oxide fuel cells, Energy, Vol. 132, pp 280-288, 2017.https://doi.org/10.1016/j.energy.2017.05.005

[9] Mortazaei, M., Rahimi, M., A comparison between two methods of generating power, heat and refrigeration via biomass based Solid Oxide Fuel Cell: A thermodynamic and environmental analysis, Energy Conversion and Management, Vol. 126, pp 132-141, 2016.

[10] Liso, V., Zhao, Y., Brandon, N., Nielsen, M. P., Kær, S. K., Analysis of the impact of heatto-power ratio for a SOFC-based mCHP system for residential application under different climate regions in Europe, International Journal of Hydrogen Energy, Vol. 36, pp 13715-13726, 2011.

[11] Bompard, E., Napoli, R., Wan, B., Orsello, G., Economics evaluation of a $5 \mathrm{~kW}$ SOFC power system for residential use, International Journal of Hydrogen Energy, Vol. 33, pp 32433247, 2008.

[12] Elmer, T., Worall, M., Wu, S., Riffat, S., Assessment of a novel solid oxide fuel cell trigeneration system for building applications, Energy Conversion and Management, Vol. 124, pp 29-41, 2016.

[13] Ho Lee, K., Strand, R.K., SOFC cogeneration system for building applications, part 2: System configuration and operating condition design, Renewable Energy, Vol. 34(12), pp 28392846, 2009.

[14] Sorace, M., Gandiglio, M., Santarelli, M., Modeling and techno-economic analysis of the integration of a FC-based micro-CHP system for residential application with a heat pump, Energy, Vol. 120, pp 262-275, 2017.

[15] Al Moussawi, H., Fardoun, F., Louahlia, H., 4-E based optimal management of a SOFCCCHP system model for residential applications, Energy Conversion and Management, Vol. 151, pp 607-629, 2017. 
[16] Fong, K.F., Lee, C.K., System analysis and appraisal of SOFC-primed micro cogeneration for residential application in subtropical region, Energy and Buildings, Vol. 128, pp 819-826, 2016.

[17] Shimoda, Y., Taniguchi-Matsuoka, A., Inoue, T., Otsuki, M., Yamaguchi, Y., Residential energy end-use model as evaluation tool for residential micro-generation, Applied Thermal Engineering, Vol. 114, pp 1433-1442, 2017.

[18] Ramadhani, F., Hussain, M.A., Mokhlis, H., Hajimolana, S., Optimization strategies for Solid Oxide Fuel Cell (SOFC) application: A literature survey, Renewable and Sustainable Energy Reviews, Vol. 76, pp 460-484, 2017.

[19] Wakui, T., Wada, N., Yokoyama, R., Feasibility study on combined use of residential SOFC cogeneration system and plug-in hybrid electric vehicle from energy-saving viewpoint, Energy Conversion and Management, Vol. 60, pp 170-179, 2012.

[20] Vialetto, G., Noro, M., Rokni, M., Combined micro-cogeneration and electric vehicle system for household application: An energy and economic analysis in a Northern European climate, International Journal of Hydrogen Energy, Vol. 42(15), pp 10285-10297, 2017.

[21] Vialetto, G., Noro, M., Rokni, M., Thermodynamic investigation of a shared cogeneration system with electrical cars for northern Europe climate, Journal of Sustainable Development of Energy, Water and Environment Systems, Vol. 5(4), pp 590-607, 2017.

[22] Frazzica, A., Briguglio, N., Sapienza, A., Freni, A., Brunaccini, G., Antonucci, V., Ferraro, M., Analysis of different heat pumping technologies integrating small scale solid oxide fuel cell system for more efficient building heating systems, International Journal of Hydrogen Energy, Vol. 40(42), pp 14746-14756, 2015.

[23] AA.VV. TRNSYS: A Transient System Simulation Program, TRNSYS Manual, Version 16. 2004

[24] Busato, F., Lazzarin, R., Noro, M., Two years of recorded data for a multisource heat pump system: A performance analysis, Applied Thermal Engineering, Vol. 57, pp 39-47, 2013.

[25] Busato, F., Lazzarin, R., Noro, M., Ground or solar source heat pump systems for space heating: Which is better? Energetic assessment based on a case history, Energy and Buildings, Vol. 102, pp 347-356, 2015.

[26] Busato, F., Lazzarin, R., Noro, M., Ten years history of a real gas driven heat pump plant: energetic, economic and maintenance issues, Applied Thermal Engineering, Vol. 31, pp 16481654, 2011.

[27] Busato, F., Lazzarin, R., Noro, M., Energy and economic analysis of different heat pump systems for space heating, International Journal of Low Carbon Technologies, Vol. 7(2), pp 104-112, 2012.

[28] Vialetto, G., Rokni, M., Innovative household systems based on solid oxide fuel cells for a northern European climate, Renewable Energy, Vol. 78, pp 146-156, 2015.

[29] Vialetto, G., Noro, M., Rokni, M., Innovative household systems based on solid oxide fuel cells for the Mediterranean climate, International Journal of Hydrogen Energy, Vol. 40, No. 41, pp 14378-14391, 2015.

[30] Kavvadias, K.C., Tosios, A.P., Maroulis, Z.B., Design of a combined heating, cooling and power system: sizing, operation strategy selection and parametric analysis, Energy Conversion and Management, Vol. 51(4), pp 833-845, 2010. 
[31] Wang, K., Li, N., Peng, J., Wang, X., Wang, C., Wang, M., A highly efficient solution for 
In this appendix, flowchart of SOFC and air mixing system are reported. For a sake of brevity, only data related to SOFC working at $20 \mathrm{~kW}$ are reported. For each point of the SOFC system (Figure A.

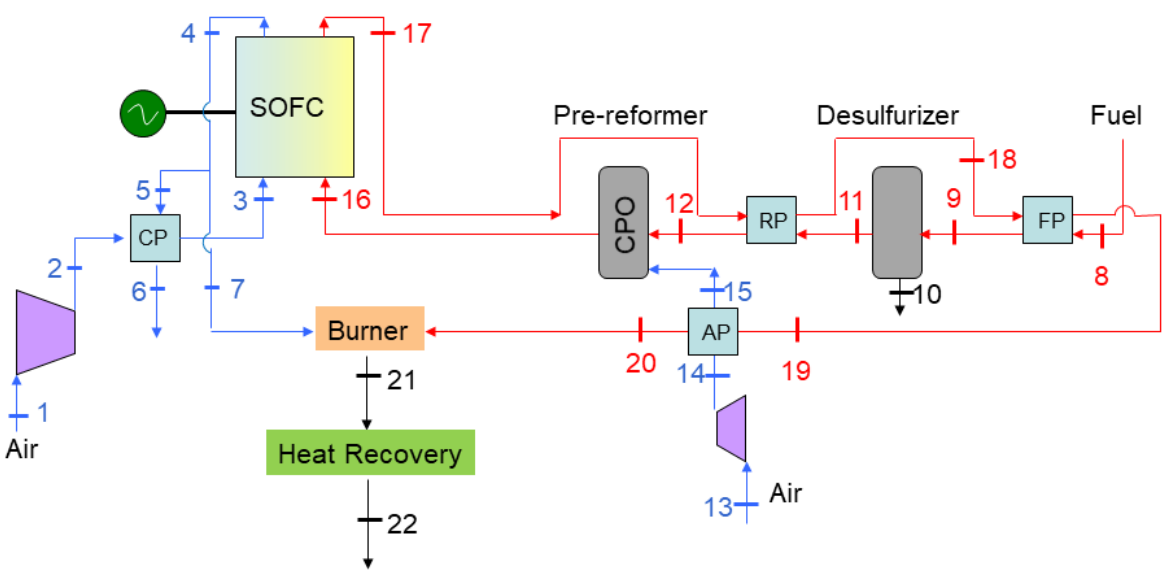

Figure A. 1. Flowchart of SOFC system (the system is the same of Figure 2).

783

Table A. 1. Data related to Figure A. 1, SOFC $20 \mathrm{~kW}$.

\begin{tabular}{|c|c|c|c|}
\hline Point & Mass flow $\left(\mathrm{kg} \mathrm{s}^{-1}\right)$ & Pressure $(\mathrm{Pa})$ & Temperature $\left({ }^{\circ} \mathrm{C}\right)$ \\
\hline 1 & 0.0325 & 101325 & -5 \\
\hline 2 & 0.0325 & 106183 & 16.2 \\
\hline 3 & 0.0325 & 105683 & 600 \\
\hline 4 & 0.0304 & 105155 & 780 \\
\hline 5 & 0.0256 & 105155 & 780 \\
\hline 6 & 0.0256 & 104655 & 40 \\
\hline 7 & $0.473 \mathrm{E}-02$ & 105155 & 780 \\
\hline 8 & $0.798 \mathrm{E}-03$ & 105860 & 20 \\
\hline 9 & $0.798 \mathrm{E}-03$ & 105760 & 200 \\
\hline 10 & $0.548 \mathrm{E}-05$ & 105660 & 200 \\
\hline 11 & $0.798 \mathrm{E}-03$ & 105660 & 200 \\
\hline 12 & $0.798 \mathrm{E}-03$ & 105560 & 525 \\
\hline 13 & $0.920 \mathrm{E}-03$ & 101325 & -5 \\
\hline 14 & $0.920 \mathrm{E}-03$ & 105560 & 1.1 \\
\hline 15 & $0.920 \mathrm{E}-03$ & 105560 & 550 \\
\hline 16 & $0.171 \mathrm{E}-02$ & 105560 & 650 \\
\hline 17 & $0.386 \mathrm{E}-02$ & 105455 & 780 \\
\hline 18 & $0.386 \mathrm{E}-02$ & 105355 & 656 \\
\hline 19 & $0.386 \mathrm{E}-02$ & 105255 & 605 \\
\hline 20 & $0.386 \mathrm{E}-02$ & 105154 & 521 \\
\hline 21 & $0.86 \mathrm{E}-02$ & 103054 & 1336 \\
\hline 22 & $0.86 \mathrm{E}-02$ & 102054 & 105 \\
\hline & & 24 & \\
\hline
\end{tabular}


In next tables (Table A. 2 to Table A. 9) data related to flowchart of Figure A. 2 are reported. For the sake of brevity, only a selection of cases are presented. Flowchart reports mass flow rate (dry mass for point 1, 2, 3 and 4, condensed water for point 31 and 41), humidity ratio, and temperature. Pressure is not reported because both exhausted gases and inlet air are just over atmospheric pressure.

791

792

793

794

795

796

797

798

799

800

801

802

803

804

805

Table A. 2. Data related to Figure A. 2: SOFC $20 \mathrm{~kW}, \mathrm{RH}=25 \%, \mathrm{~T}_{2}=-5{ }^{\circ} \mathrm{C}$

\begin{tabular}{|c|c|c|c|}
\hline Point & Mass flow $\left(\mathrm{kg} \mathrm{s}^{-1}\right)$ & $\begin{array}{c}\text { Humidity ratio } \\
\left(\mathrm{kg}_{\text {water }} \mathrm{kg}_{\text {dry air }}{ }^{-1}\right)\end{array}$ & Temperature $\left({ }^{\circ} \mathrm{C}\right)$ \\
\hline 1 & 0.0086 & 0.4255 & 105 \\
\hline 2 & 1.2834 & 0.0006 & -5 \\
\hline 3 & 1.292 & 0.0029 & -2.35 \\
\hline 31 & 0.0007 & - & -2.35 \\
\hline 4 & 1.292 & 0.0026 & -3.43 \\
\hline 41 & 0.0003 & - & -3.43 \\
\hline
\end{tabular}

Figure A. 2. Air mixing system (the system is the same of Figure 4)

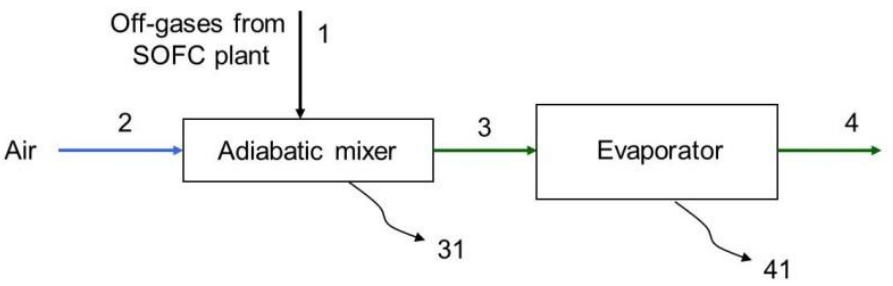

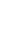

(1) 
Table A. 4. Data related to Figure A. 2: SOFC $20 \mathrm{~kW}, \mathrm{RH}=25 \%, \mathrm{~T}_{2}=+5{ }^{\circ} \mathrm{C}$

\begin{tabular}{|c|c|c|c|}
\hline Point & Mass flow $\left(\mathrm{kg} \mathrm{s}^{-1}\right)$ & $\begin{array}{c}\text { Humidity ratio } \\
\left(\mathrm{kg}_{\text {water }} \mathrm{kg}_{\text {dry air }}{ }^{-1}\right)\end{array}$ & Temperature $\left({ }^{\circ} \mathrm{C}\right)$ \\
\hline 1 & 0.009 & 0.4022 & 105 \\
\hline 2 & 1.283 & 0.0014 & 5 \\
\hline 3 & 1.292 & 0.0041 & 6.21 \\
\hline 31 & - & - & - \\
\hline 4 & 1.292 & 0.0041 & 3.50 \\
\hline 41 & - & - & - \\
\hline
\end{tabular}

807

808

809

810

811

812

813

Table A. 5. Data related to Figure A. 2: SOFC $20 \mathrm{~kW}, \mathrm{RH}=100 \%, \mathrm{~T}_{2}=+5^{\circ} \mathrm{C}$

\begin{tabular}{|c|c|c|c|}
\hline Point & Mass flow $\left(\mathrm{kg} \mathrm{s}^{-1}\right)$ & $\begin{array}{c}\text { Humidity ratio } \\
\left(\mathrm{kg}_{\text {water }} \mathrm{kg}_{\text {dry air }}{ }^{-1}\right)\end{array}$ & Temperature $\left({ }^{\circ} \mathrm{C}\right)$ \\
\hline 1 & 0.009 & 0.4022 & 105 \\
\hline 2 & 1.283 & 0.0054 & 5 \\
\hline 3 & 1.292 & 0.0071 & 8.88 \\
\hline 31 & 0.0014 & - & 8.88 \\
\hline 4 & 1.292 & 0.0064 & 7.49 \\
\hline 41 & 0.0008 & - & $7.49 \mathrm{C}$ \\
\hline
\end{tabular}

Table A. 6. Data related to Figure A. 2: SOFC $50 \mathrm{~kW}, \mathrm{RH}=25 \%, \mathrm{~T}_{2}=-5{ }^{\circ} \mathrm{C}$

\begin{tabular}{|c|c|c|c|}
\hline Point & Mass flow $\left(\mathrm{kg} \mathrm{s}^{-1}\right)$ & $\begin{array}{c}\text { Humidity ratio } \\
\left(\mathrm{kg}_{\text {water }} \mathrm{kg}_{\text {dry air }}{ }^{-1}\right)\end{array}$ & Temperature $\left({ }^{\circ} \mathrm{C}\right)$ \\
\hline 1 & 0.024 & 0.3912 & 105 \\
\hline 2 & 1.268 & 0.0006 & -5 \\
\hline 3 & 1.292 & 0.0053 & 4.6 \\
\hline 31 & 0.0033 & - & 4.6 \\
\hline 4 & 1.292 & 0.0048 & 3.35 \\
\hline 41 & 0.0006 & - & 3.35 \\
\hline
\end{tabular}

Table A. 7. Data related to Figure A. 2: SOFC $50 \mathrm{~kW}, \mathrm{RH}=100 \%, \mathrm{~T}_{2}=-5{ }^{\circ} \mathrm{C}$

\begin{tabular}{|c|c|c|c|}
\hline Point & Mass flow $\left(\mathrm{kg} \mathrm{s}^{-1}\right)$ & $\begin{array}{c}\text { Humidity ratio } \\
\left(\mathrm{kg}_{\text {water }} \mathrm{kg}_{\text {dry air }}{ }^{-1}\right)\end{array}$ & Temperature $\left({ }^{\circ} \mathrm{C}\right)$ \\
\hline 1 & 0.024 & 0.3912 & 105 \\
\hline 2 & 1.268 & 0.0023 & -5 \\
\hline 3 & 1.292 & 0.0061 & 6.67 \\
\hline 31 & 0.0044 & - & 6.67 \\
\hline 4 & 1.292 & 0.0055 & 5.35 \\
\hline 41 & 0.0007 & - & 5.35 \\
\hline
\end{tabular}


Table A. 8. Data related to Figure A. 2: SOFC $50 \mathrm{~kW}, \mathrm{RH}=25 \%, \mathrm{~T}_{2}=+5{ }^{\circ} \mathrm{C}$

\begin{tabular}{|c|c|c|c|}
\hline Point & Mass flow $\left(\mathrm{kg} \mathrm{s}^{-1}\right)$ & $\begin{array}{c}\text { Humidity ratio } \\
\left(\mathrm{kg}_{\text {water }} \mathrm{kg}_{\text {dry air }}{ }^{-1}\right)\end{array}$ & Temperature $\left({ }^{\circ} \mathrm{C}\right)$ \\
\hline 1 & 0.025 & 0.3698 & 105 \\
\hline 2 & 1.267 & 0.0014 & 5 \\
\hline 3 & 1.292 & 0.0077 & 10.12 \\
\hline 31 & 0.0010 & - & 10.12 \\
\hline 4 & 1.292 & 0.007 & 8.7 \\
\hline 41 & 0.09 & - & 8.7 \\
\hline
\end{tabular}

815

816

Table A. 9. Data related to Figure A. 2: SOFC $50 \mathrm{~kW}, \mathrm{RH}=100 \%, \mathrm{~T}_{2}=+5{ }^{\circ} \mathrm{C}$

\begin{tabular}{|c|c|c|c|}
\hline Point & Mass flow $\left(\mathrm{kg} \mathrm{s}^{-1}\right)$ & $\begin{array}{c}\text { Humidity ratio } \\
\left(\mathrm{kg}_{\text {water }} \mathrm{kg}_{\text {dry air }}{ }^{-1}\right.\end{array}$ & Temperature $\left({ }^{\circ} \mathrm{C}\right)$ \\
\hline 1 & 0.025 & 0.3698 & 105 \\
\hline 2 & 1.267 & 0.0054 & 5 \\
\hline 3 & 1.292 & 0.01 & 14.05 \\
\hline 31 & 0.0031 & - & 14.05 \\
\hline 4 & 1.292 & 0.0091 & 12.69 \\
\hline 41 & 0.0011 & - & 12.69 \\
\hline
\end{tabular}

